mina maiora Merovingica aetate per hexametros rhythmicos scripta non extent, adhuc non licebat iudicare: iam ex hac Merovingicae aetatis vita s. Eligii eorum ars quae fuerit discendum est. Nam codices adscendunt ad saeculum IX $^{8}$ ), satis corrupti : neque ullo modo fieri potest, ut carmen Karolo Magno recentius sit, cuius aetate similiter balbutire pergunt monachi Augienses ${ }^{9}$ ).

Restat, ut de carminis Lactantiani historia critica exponatur. Id vero facere non poterit nisi qui ipsos codices aut eorum ectypa viderit.

Berolini.

Paulus de Winterfeld.

\title{
6. Propertius IV 1. 31
}

(a personal explanation).

Dr. G. Ries (Philologus 1902 p. 162) has some observations upon the reading of this passage upon which I crave space to comment.

He rightly corrects the statement of Prof. A. Dietrich (Rhein. Mus. 1900) that noone had previously considered wheather the Soloni of the Neapolitan MS was possible by referring to the priority of $\mathrm{M}^{r}$ Ellis in the American Journal of Philology I S. 52 (it should be S. 396). $\quad \mathrm{M}^{\mathrm{r}}$ Ellis however had published his view eight years before in the Academy for 1873 (Feb., p. 57) as is mentioned in A. Palmer's edition of 1880. Until Dr. Ries reminded me, I had forgotten that I had condemned the view in my notice of $\mathrm{M}^{r}$ Ellis' paper of 1880. So far as I can remember after a lapse of twenty one years, this was due to a misapprehension of the very brief language in which $\mathrm{M}^{r}$ Ellis couched his suggestion. I am glad therefore to have this opportunity of stating that more than a year before Dietrich's article appeared, I had come to the conclusion that Soloni was unimpeachably right.

Another place where I now regard $\mathrm{N}$ as superior to the other Mss is at III IX. 35 'non ego uelifera tumidum mare findo carina' which is omitted in N \& which I agree with Palmer and others is an interpolation to take the place of a lost hexameter.

Cambridge. J. P. Postgate.

${ }^{8}$ ) antiquissimi sunt codices Bruxellensis n. 5374-5375 saec. IX (sic Bollandiani, catal. I p. 470 ; saec. IX vel $X$ minus recte, ni fallor, Krusch, SS. rer. Merov. IV p. 657, 29) et Parisiensis n. 5327 saec. X.

$\left.{ }^{9}\right)$ Poetae latini aevi Carolini tom. II p. 426.

April - Juli 1903. 